\title{
Effect of Fertigation Schedule on Water and Fertilizer Use Efficiency in Aerobic Rice
}

\author{
B. G. Yamuna and M. Dinesh Kumar* \\ Department of Agronomy, College of Agriculture, Shivamogga, India \\ *Corresponding author
}

\section{Keywords \\ Aerobic rice, Drip, Fertilizers, \\ Fertigation, Water soluble fertilizers \\ Article Info \\ Accepted: \\ 15 July 2020 \\ Available Online: \\ 10 August 2020}

\begin{abstract}
A B S T R A C T
Field experiments were conducted on sandy loam soils in the field unit of Agronomy division, College of Agriculture, Shivamogga, Karnataka, India during Kharif season of 2015 and 2016. In this field trial, the effect of levels and methods of fertilizer application (surface and fertigation) with combination of water soluble fertilizers and normal fertilizers or alone on growth and yield of aerobic rice was studies. The experiment was laid out in a Randomized Complete Block Design (RCBD) comprising of 3 replications and 12 treatments. Results revealed that nutrient uptake pattern increased with age till harvest for all the major elements. Nitrogen accumulation was highest (78.05 to $119.17 \mathrm{~kg}$ $\mathrm{ha}^{-1}$ ) closely followed by potassium (74.58-98.22 $\mathrm{kg} \mathrm{ha}^{-1}$ ) and phosphorus (14.80 to 20.35 $\mathrm{kg} \mathrm{ha}^{-1}$ ). Application of 100 per cent RDF along with surface irrigation resulted to accumulate $53.77 \mathrm{~kg} \mathrm{~N}^{-1}, 9.84 \mathrm{~kg} \mathrm{P} \mathrm{ha}^{-1}$ and $28.25 \mathrm{~kg} \mathrm{~K} \mathrm{ha}^{-1}$ in grains. Compared to this, plots supplied with $100\left(68.84 \mathrm{~kg} \mathrm{~N} \mathrm{ha}^{-1}, 11.87 \mathrm{~kg} \mathrm{P} \mathrm{ha}^{-1}\right.$ and $\left.31.20 \mathrm{~kg} \mathrm{~K} \mathrm{ha}^{-1}\right)$ or 125 (72.08 $\mathrm{kg} \mathrm{N} \mathrm{ha}^{-1}, 12.81 \mathrm{~kg} \mathrm{P} \mathrm{ha}^{-1}$ and $32.53 \mathrm{~kg} \mathrm{~K} \mathrm{ha}^{-1}$ ) per cent RDF through fertigation or conjunction of 25 per cent RDF through soil along with $75\left(71.06 \mathrm{~kg} \mathrm{~N} \mathrm{ha}^{-1}, 12.44 \mathrm{~kg} \mathrm{P}^{-}\right.$ ${ }^{1}$ and $\left.31.73 \mathrm{~kg} \mathrm{~K} \mathrm{ha}^{-1}\right)$ or $100\left(74.34 \mathrm{~kg} \mathrm{~N} \mathrm{ha}^{-1}, 13.55 \mathrm{~kg} \mathrm{P} \mathrm{ha}^{-1}\right.$ and $\left.33.66 \mathrm{~kg} \mathrm{~K} \mathrm{ha}^{-1}\right)$ per cent RDF through fertigation maintained higher uptake in grains. Further, these group of treatments performed best for achieving yield (60.95-68.92 $\mathrm{q} \mathrm{ha}^{-1}$ grain) with higher water

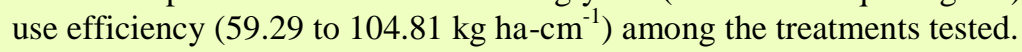

\section{Introduction}

Rice (Oryza sativa L.) is the most important staple food for more than half the planet's population and is a water intensive enterprise. It is cultivated in different ecosystems in many ways. India being the second largest producer of world (106.57 $\mathrm{mt})$, covers an area of $43.97 \mathrm{~m}$ ha with the productivity level of $2424 \mathrm{~kg} \mathrm{ha}^{-1}$ (Anon., 2016). As the water use efficiency of rice is very low and loss of applied fertilizers in the field is more, it creates challenges for rice cultivation. So, adoption of aerobic rice system holds well in the present condition.

Achieving consistent high yields depends on better management of soil with water and in particular applied inputs. Optimizing the fertilizer requirements is influenced by many location specific factors which also include resource management at its best. Maximum 
yields are obtained when optimum quantities of nutrients are provided for a crop. The suitable agronomic practices can modify the environment to certain extent and thereby help the crop to utilize the available resource efficiently to achieve higher production. Nutrient bio-availability is a function of both plant and soil factors that can be altered by water management particularly in relation to the conditions in rhizosphere. Biogeochemical modelling based on bulk soil conditions emphasizes on dissolved organic ions, $\mathrm{pH}$ and redox conditions as major determinants apart from chemical properties of soil and biological processes in rhizosphere. In order to avail relatively mobile elements into the root zone, suitable modifications such as drip system of water distribution, fertigation, etc. are very helpful.

Increased total dry matter in rice is well accomplished with higher photosynthesis and NPK uptake which transmits the nutrients to grains and straw. Hence, nutrient uptake is a function of biomass and nutrient concentrations in plant. Yield maximization of any crop demands on the process associated with uptake of nutrients, translocation, retention, partitioning, assimilation and mobilization of nutrients at different growth stages. These multitude processes are influenced by genetic potential of variety, cultural practices, soil manipulation and climatic factors. The enhancement of nutrient content in any given situation rests on availability of nutrients from the soil through added manures and fertilizers. The growth enhancement also depends on nutrients as a part of inorganic constituent in plant system. Hence, growth i.e. biomass and nutrient uptake are synergistic in bringing the crop for healthy production. Hence, Production capacity of soil needs to be addressed properly to augment the nutrient uptake by crop plants timely.
Simultaneous use of drip irrigation and fertilizer application (fertigation) opens up new possibilities for controlling water and timely nutrient supply to crops besides maintaining the desired concentration and distribution of nutrients and water into the soil. Fertigation gives advantages such as higher use efficiency of water and fertilizer, minimum losses of $\mathrm{N}$ due to leaching, supplying nutrients directly to root zone in available forms, control of nutrient concentration in soil solution and saving in application cost. Thus, fertigation becomes prerogative for increasing the yield of most of the crops under drip irrigation. Water soluble fertilizers having high content of nutrients with low salt index can be used for fertigation (Nitika et al., 2014). As water soluble fertilizers are very costly inputs, efforts should be made to reduce the quantity of water soluble fertilizers in conjunction with normal fertilizers (Yanglem and Tumbare, 2014) Keeping the above facts in mind, the present study was conducted with the objective to determine the combined fertilizer rates for getting highest growth and yield aerobic rice production through drip fertigation.

\section{Materials and Methods}

Field studies were conducted during the regular kharif rice growing season of 2015 and 2016 in the Field Unit of Agronomy Department of College of Agriculture, UAHS, Shivamogga (latitude $13^{\circ} 58^{\prime}$ North, longitude $75^{\circ} 34^{\prime}$ East longitude with an altitude of 650 m MSL), located under Southern Transition Zone of Karnataka. The experimental soil had sandy loam texture with a predominance of illite clay mineral which is taxonomically classified under the major group Typic haplustept. The experiment was laid out in a Randomized Complete Block Design (RCBD) comprising 3 replications and 12 treatments viz., $\mathrm{T}_{1}: 75 \% \mathrm{RDF}$ through fertigation; $\mathrm{T}_{2}$ : 
$100 \%$ RDF through fertigation; $\mathrm{T}_{3}: 125 \%$ RDF through fertigation; $\mathrm{T}_{4}: 50 \%$ RDF- soil application $+25 \% \mathrm{RDF}$ - fertigation; $\mathrm{T}_{5}: 50 \%$ RDF- soil application $+50 \%$ RDF fertigation; $\mathrm{T}_{6}: 50 \%$ RDF- soil application + $75 \%$ RDF - fertigation; $\mathrm{T}_{7}: 25 \%$ RDF- soil application $+50 \% \mathrm{RDF}$ - fertigation; $\mathrm{T}_{8}: 25 \%$ RDF - soil application + 75\% RDF fertigation; $\mathrm{T}_{9}: 25 \% \mathrm{RDF}$ - soil application + $100 \%$ RDF - fertigation; $\mathrm{T}_{10}: 75 \% \mathrm{RDF}$ through soil application; $\mathrm{T}_{11}: 100 \% \mathrm{RDF}$ through soil application and $\mathrm{T}_{12}: 125 \% \mathrm{RDF}$ through soil application11111.Based on 1.0 $\mathrm{PE}$, fertigation is scheduled for 8 equal splits at 10, 20, 30, 40, 50, 60, 70 and 80 DAS. The aerobic rice cultivar used was MAS 946-1 (Sharada). Seeds were dibbled at $25 \mathrm{~cm} \mathrm{X} 25$ $\mathrm{cm}$ apart. Recommended Farm Yard Manure was applied at the rate of $10 \mathrm{t} \mathrm{ha}^{-1}$ two weeks before sowing for all the treatments. The recommended dose of fertilizers (100: 50: 50 of NPK kg ha ${ }^{-1}$ and zinc sulphate @ $20 \mathrm{~kg} \mathrm{ha}$ $\left.{ }^{1}\right)$ were applied as per the treatments. The sources of nutrients for water soluble fertilizers used were 19:19:19 and calcium ammonium nitrate $(15.5 \% \mathrm{~N}$ and $17 \% \mathrm{Ca})$. In standard soil application, the sources of nutrients applied were in the form of urea (46 $\% \mathrm{~N})$, single super phosphate $\left(16 \% \mathrm{P}_{2} \mathrm{O}_{5}\right)$ and muriate of potash $\left(60 \% \mathrm{~K}_{2} \mathrm{O}\right)$. As per the treatment details, NPK was applied through drip-fertigation method by using ventury system to each plot up to 80 days after sowing at ten days interval. For standard soil application treatments, out of the recommended dose of fertilizers, 50 per cent of recommended nitrogen \& potassium and entire dose of phosphorous were applied as basal dose. Remaining 50 per cent of recommended nitrogen was applied in two splits once at 30 days after sowing and another at 55-60 days just before panicle emergence along with 50 per cent of recommended potassium. The data pertaining to the experiment were subjected to statistical analysis and results were compared.

\section{Results and Discussion}

From the beginning of the growth, it is observed that plots applied with 100 or 125 per cent RDF through fertigation or conjunction of 25 per cent RDF through soil along with 75 or 100 per cent RDF through fertigation maintained higher major nutrients in straw (Fig. 1) up to peak period of growth i.e. 90 DAS and then declined due to diversion of nutrients to sink part. Fageria and Baliger (2003) reported that in cereals including rice, $\mathrm{N}$ accumulation is associated with dry matter production and yield of grains

It is seen from the data (Fig. 2) that application of 100 per cent RDF along with surface irrigation resulted to accumulate $53.77 \mathrm{~kg} \mathrm{~N} \mathrm{ha}^{-1}, 9.84 \mathrm{~kg} \mathrm{P} \mathrm{ha}^{-1}$ and $28.25 \mathrm{~kg}$ $\mathrm{K} \mathrm{ha}^{-1}$ in grains. Compared to this, plots supplied with $100\left(68.84 \mathrm{~kg} \mathrm{~N} \mathrm{ha}^{-1}, 11.87 \mathrm{~kg}\right.$ $\mathrm{P} \mathrm{ha}^{-1}$ and $\left.31.20 \mathrm{~kg} \mathrm{~K} \mathrm{ha}^{-1}\right)$ or $125(72.08 \mathrm{~kg}$ $\mathrm{N} \mathrm{ha}^{-1}, 12.81 \mathrm{~kg} \mathrm{P} \mathrm{ha}^{-1}$ and $32.53 \mathrm{~kg} \mathrm{~K} \mathrm{ha}^{-1}$ ) per cent RDF through fertigation or conjunction of 25 per cent RDF through soil along with $75\left(71.06 \mathrm{~kg} \mathrm{~N} \mathrm{ha}^{-1}, 12.44 \mathrm{~kg} \mathrm{P} \mathrm{ha}^{-}\right.$ ${ }^{1}$ and $\left.31.73 \mathrm{~kg} \mathrm{~K} \mathrm{ha}^{-1}\right)$ or $100\left(74.34 \mathrm{~kg} \mathrm{~N} \mathrm{ha}^{-}\right.$ ${ }^{1}, 13.55 \mathrm{~kg} \mathrm{P} \mathrm{ha}^{-1}$ and $33.66 \mathrm{~kg} \mathrm{~K} \mathrm{ha}^{-1}$ ) per cent RDF through fertigation maintained higher uptake in grains and obviously these group of treatments performed best for achieving yield among the treatments tested. Tsujimoto et al., (2009) reported that average mineralizable $\mathrm{N}$ at depths of $0-30 \mathrm{~cm}$ was linearly related to rice grain yields irrespective of management practices.

In general, nutrient uptake pattern as seen from the studies increased with age till harvest for all the major elements. Among them nitrogen accumulation from the plants was highest as the values ranged from 78.05 to $119.17 \mathrm{~kg} \mathrm{ha}^{-1}$ closely followed by potassium (74.58-98.22 $\mathrm{kg} \mathrm{ha}^{-1}$ ) uptake. The uptake of phosphorus was lower ranged from 14.80 to $20.35 \mathrm{~kg} \mathrm{ha}^{-1}$. Treatments 75 per cent 
RDF through Soil application with surface irrigation recorded lowest and 25 per cent RDF through soil application and 100 per cent RDF through fertigation recorded highest uptake of major nutrients, while trend of effect by treatments remained same to that of grain and straw at harvest. The fertigation mode of application resulted into ready availability of nutrients in the root zone, promoting uptake as per need and as a result the content of particular nutrients also found relatively more compared to soil application, wherein likely losses of nutrients due to various mechanisms limit the availability into the root zone causing lesser uptake. Gratez et al., (1978) suggested that the faster discharge rates might improve the distribution of soluble nutrients particularly for surface rooting crops. Potassium ion is normally adsorbed at the cation exchange sites of the soil colloids. The results corroborate the findings of Chesti et al., (2013).

Based on the amount of nutrients supplied and corresponding yield, nutrient use efficiency calculated (Table 1) showed significant difference due to method of fertilizer application through soil and fertigation. Use efficiencies will be higher at lesser applications of nutrients, with each addition of nutrient response increment is likely to reduce with respect to all nutrients because of nature of growth curve that follows sigmoid type as synthates re-orient for economic parts. In this context, the highest nitrogen use efficiency was observed in the plots receiving lesser quantity of fertilizers as the amount increases it decreased for all the major nutrients studied. The $\mathrm{N}$ use efficiency ranged from 40.46 to $68.92 \mathrm{~kg} \mathrm{~kg}^{-1}$ in different treatments. The application quantity of $\mathrm{P}$ and $\mathrm{K}$ being same $\left(50 \mathrm{~kg} \mathrm{ha}^{-1}\right)$, the use efficiency computations remained same, in that the values ranged from 73.72 to $134.85 \mathrm{~kg} \mathrm{ha}^{-1}$. Application of recommended fertilizers in different splits as per crop needs at frequent intervals favoured efficient absorption by the crop with least or negligible loss enhanced the use efficiency of nutrients. These results are in conformity with Hebbar et al., (2004) and Shaymaa et al., (2009).

In the present study, the total water used in surface irrigation was $1003.2 \mathrm{~mm}$ as against $657.6 \mathrm{~mm}$ for drip system (Table 1). Further, quantity of fertilizers added differed with its mode of application. It is observed from the data that yield variations occurred in tune with gradation of fertilizer. Surface irrigation with 75 or 100 or 125 per cent RDF application through soil resulted grain yield variations from 36.86 to $52.38 \mathrm{q} \mathrm{ha}^{-1}$ and hence water use efficiency also varied. It was $36.74-50.41 \mathrm{~kg}$ ha- $\mathrm{cm}^{-1}$ of water. On the similar lines, drip irrigated plots with different rates of fertilizers through fertigation recorded water use efficiency ranging from 59.29 to

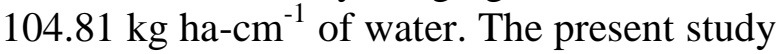
emphasizes better water use efficiency through fertigation was achieved. The higher water use efficiency with drip system was attributed to reduced water loss and efficient water use by the plants resulting in higher yield. Favourable effect of drip irrigation is on maintenance of constant soil moisture potential without causing severe aeration problems. The lower water use efficiency of aerobic rice with surface irrigation was attributed to more evaporation loss of soil moisture due to more exposed wetting surface upon irrigation apart from reduced grain yield as compared to drip irrigation. Similar results were also reported by Pushpa et al., (2007). The correlation and regression calculations were worked out for yield and to that of nutrient uptake. It is seen from the data that with high correlation co-efficient, regressed yield by uptake is highly dependent (Table 3 ).

High crop yields are determined by ability of plants to produce high levels of photoassimilate and/or to partition large 
proportions of carbohydrate efficiently into harvestable organs. Variations accrued in nutrient uptake and growth due to application of treatments essentially reflects in achieving final harvestable yield (Table 2). Among the treatments in test, application of 25 per cent RDF through soil and 100 per cent RDF through fertigation resulted higher grain yield
(68.92 $\left.\mathrm{q} \mathrm{ha}^{-1}\right)$ and straw yield (79.45 $\mathrm{q} \mathrm{ha}^{-1}$ ) and found statistically on par with treatments such as application of 100 or 125 per cent RDF through fertigation and conjunction of 25 per cent RDF through soil along with 75 per cent RDF through fertigation for grain (60.95-68.92 $\mathrm{q} \mathrm{ha}^{-1}$ grain and 69.80-74.13 q $\mathrm{ha}^{-1}$ straw respectively).

Table.1 Total water used (mm), water use efficiency $\left(\mathrm{kg} \mathrm{ha}-\mathrm{cm}^{-1}\right)$ and use efficiency of nutrients $\left(\mathrm{kg} \mathrm{kg}^{-1}\right)$ of aerobic rice as influenced by fertilizer levels applied through conventional and fertigation methods (pooled for 2014-15)

\begin{tabular}{|c|c|c|c|c|c|c|}
\hline \multirow{2}{*}{ Treatments } & \multirow{2}{*}{$\begin{array}{c}\text { Irrigation } \\
\text { water } \\
\text { used }\end{array}$} & \multirow{2}{*}{$\begin{array}{c}\text { Total } \\
\text { water } \\
\text { used } \\
\left(\mathbf{I}_{\mathbf{R}}+\mathbf{E}_{\mathbf{R}}\right)\end{array}$} & \multirow[t]{2}{*}{ WUE } & \multicolumn{3}{|c|}{ Use efficiency of nutrient } \\
\hline & & & & Nitrogen & Phosphorus & Potasium \\
\hline $\mathrm{T}_{1}-75 \% \mathrm{RDF}$ through fertigation & 339.5 & 657.6 & 76.90 & 67.43 & 134.85 & 134.85 \\
\hline$T_{2}-100 \%$ RDF through fertigation & 339.5 & 657.6 & 92.69 & 60.95 & 121.90 & 121.90 \\
\hline$T_{3}-125 \%$ RDF through fertigation & 339.5 & 657.6 & 101.72 & 53.51 & 99.10 & 99.10 \\
\hline $\begin{array}{l}\mathrm{T}_{4}-50 \% \text { RDF - soil application }+25 \% \text { RDF - } \\
\text { fertigation }\end{array}$ & 339.5 & 657.6 & 59.29 & 51.99 & 103.97 & 103.97 \\
\hline $\begin{array}{l}\mathrm{T}_{5}-\mathbf{5 0} \% \mathrm{RDF} \text { - soil application }+\mathbf{5 0 \%} \mathrm{RDF}- \\
\text { fertigation }\end{array}$ & 339.5 & 657.6 & 73.62 & 48.41 & 96.82 & 96.82 \\
\hline $\begin{array}{l}\mathrm{T}_{6}-50 \% \mathrm{RDF}-\text { soil application }+75 \% \mathrm{RDF}- \\
\text { fertigation }\end{array}$ & 339.5 & 657.6 & 87.99 & 46.29 & 85.72 & 85.72 \\
\hline $\begin{array}{l}\mathrm{T}_{7}-25 \% \text { RDF - soil application }+50 \% \text { RDF - } \\
\text { fertigation }\end{array}$ & 339.5 & 657.6 & 72.73 & 63.77 & 127.55 & 127.55 \\
\hline $\begin{array}{l}T_{8}-25 \% \text { RDF - soil application }+75 \% \text { RDF - } \\
\text { fertigation }\end{array}$ & 339.5 & 657.6 & 99.24 & 65.26 & 130.52 & 130.52 \\
\hline $\begin{array}{l}\mathrm{T}_{9}-25 \% \mathrm{RDF} \text { - soil application }+100 \% \mathrm{RDF}- \\
\text { fertigation }\end{array}$ & 339.5 & 657.6 & 104.81 & 68.92 & 102.10 & 102.10 \\
\hline $\begin{array}{l}\mathrm{T}_{10}-75 \% \text { RDF through soil application with } \\
\text { surface irrigation }\end{array}$ & 685.0 & 1003.2 & 36.74 & 49.15 & 73.72 & 73.72 \\
\hline $\begin{array}{l}T_{11}-100 \% \text { RDF through soil application with } \\
\text { surface irrigation }\end{array}$ & 685.0 & 1003.2 & 42.98 & 43.12 & 86.24 & 86.24 \\
\hline $\begin{array}{l}\mathrm{T}_{12}-125 \% \text { RDF through soil application with } \\
\text { surface irrigation }\end{array}$ & 685.0 & 1003.2 & 50.41 & 40.46 & 74.92 & 74.92 \\
\hline S.Em. \pm & NA & NA & 3.60 & 2.30 & 4.50 & 4.50 \\
\hline $\mathrm{CD}(\mathrm{P}=0.05)$ & NA & NA & 10.90 & 6.90 & 13.50 & 13.50 \\
\hline CV (\%) & NA & NA & 8.8 & 7.9 & 7.7 & 7.7 \\
\hline
\end{tabular}

RDF: 100:50:50 kg NPK ha ${ }^{-1}$; NA: Not analysed;

Effective rainfall during 2015:371.84 $\mathrm{mm}$ and 2016:264.46 $\mathrm{mm}$ 
Table.2 Grain yield and straw yield of aerobic rice as influenced by fertilizer levels applied through conventional and fertigation methods

\begin{tabular}{|c|c|c|c|c|c|c|}
\hline \multirow[t]{2}{*}{ Treatments } & \multicolumn{3}{|c|}{ Grain yield $\left(\mathrm{q} \mathrm{ha}^{-1}\right)$} & \multicolumn{3}{|c|}{ Straw yield $\left(q\right.$ ha $\left.^{-1}\right)$} \\
\hline & 2015 & 2016 & Pooled & 2015 & 2016 & Pooled \\
\hline$T_{1}-75 \%$ RDF through fertigation & 51.62 & 49.52 & 50.57 & 64.47 & 63.22 & 63.84 \\
\hline$T_{2}-100 \%$ RDF through fertigation & 61.80 & 60.11 & 60.95 & 70.42 & 69.17 & 69.80 \\
\hline$T_{3}-125 \%$ RDF through fertigation & 67.58 & 66.20 & 66.89 & 79.08 & 76.70 & 77.89 \\
\hline$T_{4}-50 \%$ RDF - soil application $+25 \%$ RDF - fertigation & 39.75 & 38.24 & 38.99 & 49.66 & 48.55 & 49.10 \\
\hline $\mathrm{T}_{5}-\mathbf{5 0} \% \mathrm{RDF}$ - soil application $+\mathbf{5 0} \% \mathrm{RDF}$ - fertigation & 49.29 & 47.52 & 48.41 & 58.88 & 57.54 & 58.21 \\
\hline$T_{6}-50 \%$ RDF - soil application $+75 \%$ RDF - fertigation & 58.63 & 57.09 & 57.86 & 69.86 & 68.28 & 69.07 \\
\hline $\mathrm{T}_{7}-25 \% \mathrm{RDF}$ - soil application $+\mathbf{5 0} \% \mathrm{RDF}$ - fertigation & 44.00 & 48.66 & 47.83 & 59.64 & 57.72 & 58.68 \\
\hline $\mathrm{T}_{8}-25 \% \mathrm{RDF}$ - soil application $+75 \% \mathrm{RDF}$ - fertigation & 66.23 & 64.29 & 65.26 & 74.75 & 73.50 & 74.13 \\
\hline $\begin{array}{l}\mathrm{T}_{9}-25 \% \text { RDF }- \text { soil application }+100 \% \text { RDF - } \\
\text { fertigation }\end{array}$ & 69.47 & 68.37 & 68.92 & 80.98 & 77.92 & 79.45 \\
\hline $\begin{array}{l}T_{10}-75 \% \text { RDF through soil application with surface } \\
\text { irrigation }\end{array}$ & 37.26 & 36.45 & 36.86 & 43.54 & 42.29 & 42.91 \\
\hline $\begin{array}{l}T_{11}-100 \% \text { RDF through soil application with surface } \\
\text { irrigation }\end{array}$ & 43.04 & 42.19 & 43.12 & 51.11 & 49.91 & 50.51 \\
\hline $\begin{array}{l}T_{12}-125 \% \text { RDF through soil application with surface } \\
\text { irrigation }\end{array}$ & 50.52 & 49.63 & 50.57 & 61.46 & 59.53 & 60.50 \\
\hline S.Em. \pm & 3.20 & 3.26 & 3.06 & 3.77 & 3.02 & 3.36 \\
\hline $\mathrm{CD}(\mathbf{P}=\mathbf{0 . 0 5})$ & 9.41 & 9.57 & 8.98 & 11.00 & 8.88 & 9.86 \\
\hline CV $(\%)$ & 10.8 & 11.3 & 10.5 & 10.3 & 8.5 & 9.3 \\
\hline
\end{tabular}

RDF: 100:50:50 kg NPK ha ${ }^{-1}$

Table.3 Regression response for grain yield and major nutrient uptake

\begin{tabular}{|l|l|c|c|l|}
\hline Year & \multicolumn{1}{|c|}{ Response curve } & $\mathbf{r}$ & $\mathbf{R}^{2}$ & \\
\hline $\mathbf{2 0 1 5}$ & $\mathrm{Y}=-20.480+0.717 \mathrm{x}_{1}$ & 0.861 & 0.743 & $\mathrm{Y}=$ Grain yield \\
& $\mathrm{Y}=-26.749+4.627 \mathrm{x}_{2}$ & 0.859 & 0.738 & $\mathrm{x}_{1}$-N uptake \\
& $\mathrm{Y}=-52.454+1.189 \mathrm{x}_{3}$ & 0.764 & 0.584 & $\mathrm{x}_{2}$-P uptake \\
& $\mathrm{Y}=-33.099+0.371 \mathrm{x}_{1}+2.248 \mathrm{x}_{2}+0.107 \mathrm{x}_{3}$ & 0.891 & 0.795 & $\mathrm{x}_{3}-\mathrm{K}$ uptake \\
\hline \multirow{2}{*2016}{} & $\mathrm{Y}=-24.469+0.769 \mathrm{x}_{1}$ & 0.909 & 0.827 & \\
& $\mathrm{Y}=-24.819+4.563 \mathrm{x}_{2}$ & 0.821 & 0.674 & \\
& $\mathrm{Y}=-59.612+1.296 \mathrm{x}_{3}$ & 0.810 & 0.657 & \\
& $\mathrm{Y}=-32.220+0.592 \mathrm{x}_{1}+1.209 \mathrm{x}_{2}+0.057 \mathrm{x}_{3}$ & 0.920 & 0.846 & \\
\hline \multirow{2}{*}{ Combined } & $\mathrm{Y}=-22.099+0.738 \mathrm{x}_{1}$ & 0.884 & 0.782 & \\
& $\mathrm{Y}=-25.699+4.577 \mathrm{x}_{2}$ & 0.840 & 0.706 & \\
& $\mathrm{Y}=-54.265+1.221 \mathrm{x}_{3}$ & 0.783 & 0.614 & \\
& $\mathrm{Y}=-31.746+0.492 \mathrm{x}_{1}+1.674 \mathrm{x}_{2}+0.070 \mathrm{x}_{3}$ & 0.902 & 0.815 & \\
\hline
\end{tabular}

Note: The independent variable $\mathrm{x}$ refers to the parameters listed in serial number

$\mathrm{Y}$ is dependent variable grain yield in $\mathrm{kg} \mathrm{ha}^{-1}$

**Correlation is significant at $\mathrm{P}=0.01=0.413$

$*$ Correlation is significant at $\mathrm{P}=0.05=0.321$ 
Fig.1 Major Nutrient uptake $\left(\mathrm{kg} \mathrm{ha}^{-1}\right)$ of straw of aerobic rice as influenced by fertilizer levels applied through conventional and fertigation methods

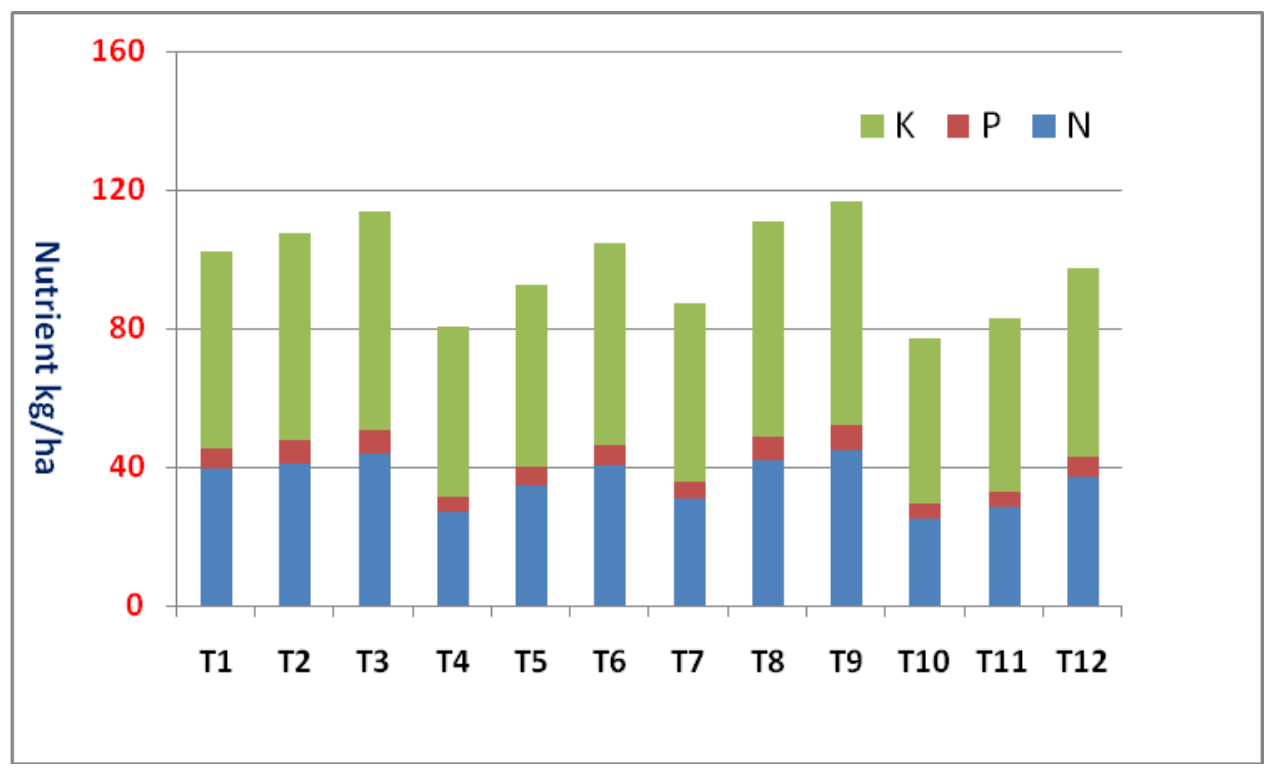

Fig.2 Major Nutrient uptake $\left(\mathrm{kg} \mathrm{ha}^{-1}\right)$ of grain of aerobic rice as influenced by fertilizer levels applied through conventional and fertigation methods

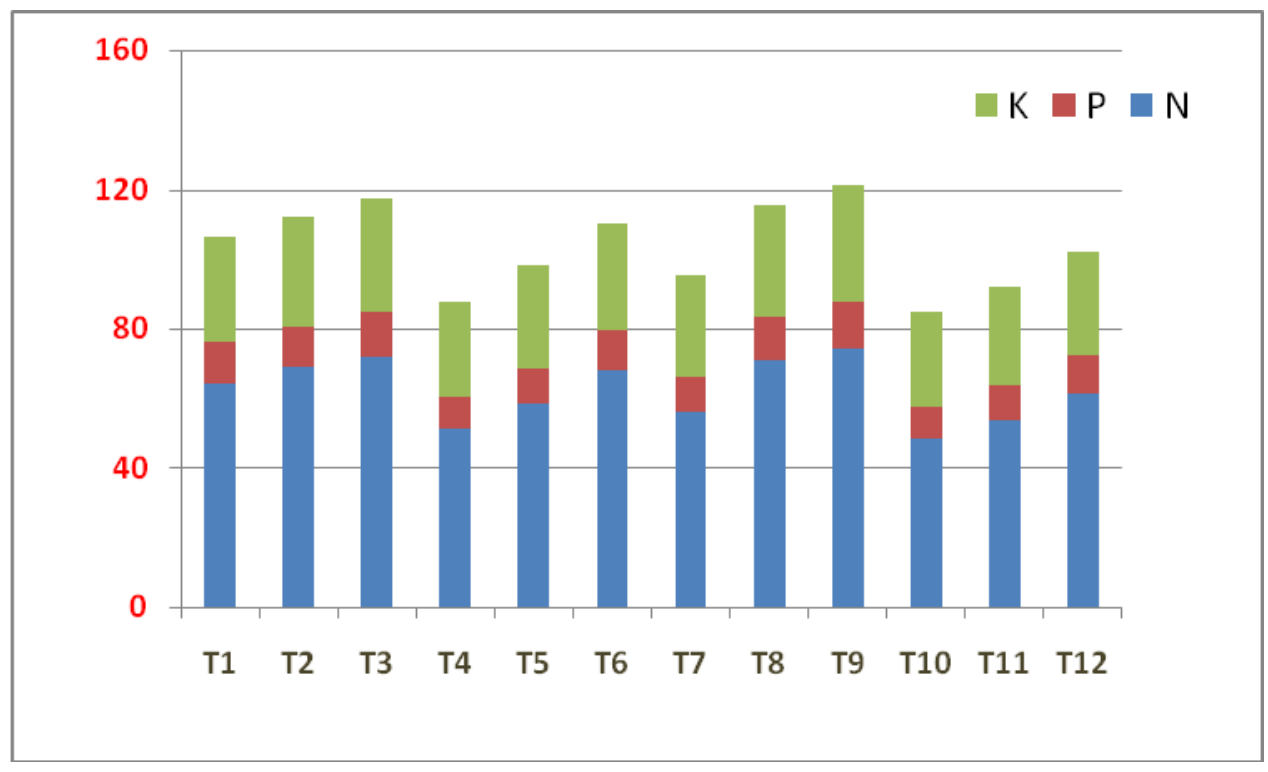

Compared to 100 per cent RDF through soil application with surface irrigation, the maximum yield treatment recorded higher yield of $80 \& 57$ per cent respectively for grain and straw whereas on par treatments at higher hierarchy recorded 59-71 \& 38-46 per cent enhancement. Application of straight fertilizers in combination with water soluble fertilizers is best alternative source to water soluble fertilizers alone. These findings are also in accordance with Anusha (2015).

From two years of study, it is concluded that application of 25 per cent RDF through soil 
and 75 per cent RDF through fertigation or else $100 \mathrm{RDF}$ through fertigation found better.

\section{References}

Anonymous, 2016, Rice - statistics and facts. http://www.statista.com/topics/ 1443/ricel.

Anusha, S., 2015, Studies on drip fertigation in aerobic rice (Oryza sativa L.). Ph.D. (Agri.) Thesis, Univ. Agril. Sci., Bengaluru.

Chesti, M. H., Kohli, A. and Sharma, A. K., 2013, Effect of integrated nutrient management on yield and nutrient uptake by wheat (Triticum aestivum) and soil properties under intermediate zone of Jammu and Kashmir. J. Indian Soc. Soil Sci., 61(1): 1-6.

Fageria, N. K. And Baligar, V. C., 2003, Fertility management of tropical acid soils for sustainable crop production. Handbook of Soil Acidity, Marcel Dekker, New York. pp. 359-385.

Gratez, D. A., Fiskell, J. G. A. and Myers, J. M., 1978, Chloride and bromide movement with trickle irrigation of bell peppers. Proc.Flo. State Hort. Soc.,91: 319-322.

Hebbar, S. S., Ramachandrappa, B. K., Nanjappa, H. V. and Prabhakar, M., 2004, Studies on NPK drip fertigation in field grown tomato (Lycopersicon esculentum Mill.). Euro. J. Agron., 21: 117-127.

Nitika, S., Sunita, J., Battan, K. R. and Jain,
R. K., 2012, Aerobic rice genotypes displayed greater adaptation to waterlimited cultivation and tolerance to polyethyleneglycol-6000 induced stress. Physiol. Mol. Biol. Plants, 18(1): 33-43.

Pushpa, K., Devakumar, N., Murthy, R. K., Nagaraju and Krishnamurthy 2007. Nutrient uptake of rice as influenced by methods of irrigation and nitrogen sources. Env. Eco., 25(4): 748-751.

Shyamaa, I., Shedeed., Sahar, M. and Yassen, A. A., 2009, Effect of method and rate of fertilizer application under drip irrigation on yield and nutrient uptake by tomato. Ozean J. App. Sci., 2(2): 139-147.

Tsujimoto, Y., Horie, T., Randriamihary, H., Shiraiwa, T. and Homma, K., 2009, Soil management: the key factors for higher productivity in the fields utilizing the system of rice intensification (SRI) in the central highland of Madagascar. Agri. System, 100: 61-71.

Yanglem, S.D. and Tumbare, A.D. 2014. Influence of irrigation regimes and fertigation levels on yield and physiological parameters in cauliflower. The Bioscan. 9(2): 589594.

Yanglem, S.D. and Tumbare, A.D. 2014. Influence of irrigation regimes and fertigation levels on yield and physiological parameters in cauliflower. The Bioscan. 9(2): 589594.

\section{How to cite this article:}

Yamuna, B. G. and Dinesh Kumar, M. 2020. Effect of Fertigation Schedule on Water and Fertilizer Use Efficiency in Aerobic Rice. Int.J.Curr.Microbiol.App.Sci. 9(08): 1253-1260. doi: https://doi.org/10.20546/ijcmas.2020.908.141 